\title{
IMPROVING BIOgAS PRODUCTION USING DifFERENT PRETREATMENT OF RICE HUSK INOCULATED With OSTRICH DUNG
}

\author{
Huda Jassim *, and Amal H. Khalil \\ Department of Environmental Engineering, College of Engineering, \\ University of Babylon, Iraq
}

\begin{abstract}
The increased demand for fossil fuel due to its huge importance in global energy has caused many problems to the environment both locally and globally. This study investigated the feasibility of the anaerobic co-digestion using rise husks as a biomass waste source and ostrich dung as a source of inoculum for biogas production as renewable energy. Samples of grounded RH were pretreated with ultrasound, hydrothermal, combined hydrothermal-ultrasonic, $\mathrm{NaOH}(3 \% \mathrm{w} / \mathrm{v})$ and combined $3 \% \mathrm{NaOH}$-ultrasound pretreatment. The cumulative production of biogas for the pretreated samples was 44.19, 39.5, 46.3, 47.16 and $52.38 \mathrm{ml} / \mathrm{g} \mathrm{VS}$, respectively. The results stated the increase in biogas generation by 50.72, 34.72, 57.91, 60.85 and $78.65 \%$, respectively, as compared to untreated sample that produced $29.32 \mathrm{ml} / \mathrm{g} \mathrm{VS}$ of biogas. The results of methane productivity, which were $30.73,26.78,32.24,32.91$ and $37.3 \mathrm{ml} / \mathrm{g} \mathrm{VS}$, respectively; for the pretreated samples with the same arrangement mentioned above, caused an increment by 66.11, 44.76, 74.27, 77.89, 101.62\%, respectively, as compared to methane yield of the untreated sample that resulted in $18.5 \mathrm{ml} / \mathrm{g}$ VS. It was observed that there was well compatibility between estimated and predicted values for methane ( $>0.95)$ using modified Gompertz model. The improvements in biogas and methane yield pointed out the anaerobic codigestion of rice husks after pretreatment inoculated with ostrich dung is a promising technology to produce renewable energy. The use of ostrich dung encouraged biogas productivity. In addition, Biogas can reduce environmental pollution by managing wastes.
\end{abstract}

Keywords: Biogas; Co-digestion; Hydrothermal; Ultrasound, Rice husks; Ostrich dung.

تحسين إنتاج الغاز الحيوي باستخذام معالجات مسبقة مختلفة لقثور الأرز الملقح بفضلات النعام

هدى جاسم* ، امال حمزة خليل

الملخص: ان الطلب المتز ابد للوقود الاحفوري نسبة الى اهميته الكبرى في الطاقة العالمية ادت الى عدة مشاكل للبيئة محليا

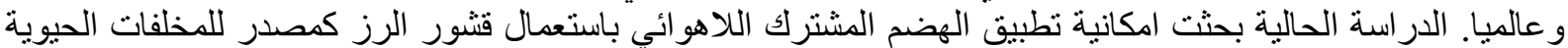

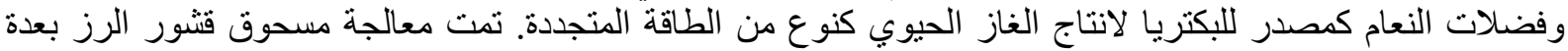

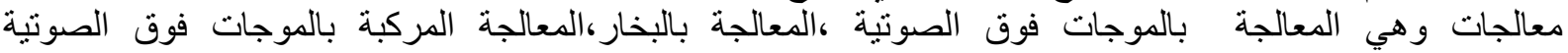

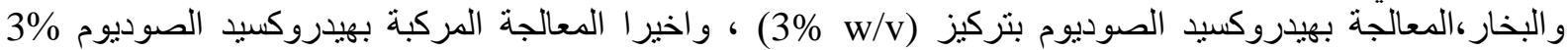

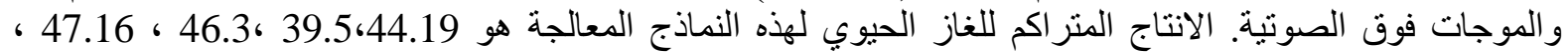

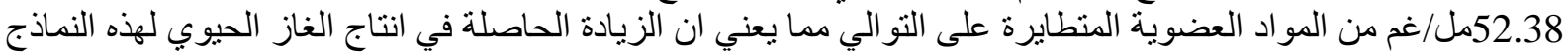

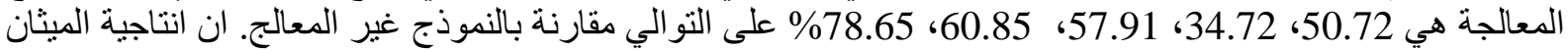

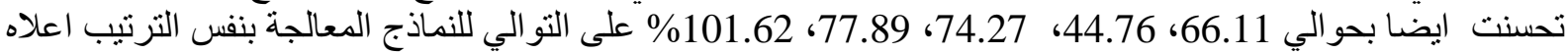
مقارنة بالنموذج غير المعالج. لقد اظهرت النتائج بان هناك تطابق بين النتائج المختبرية والنتائج النظرية عند الندان تطبيق

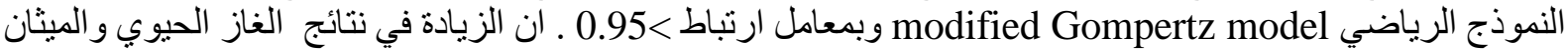

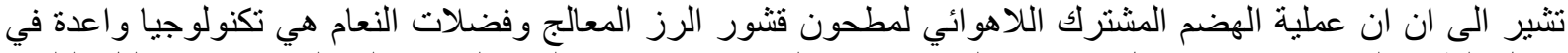
مجال الطاقة المتجددة. ان استعمال فضلات النعام قد ادى الى تعزيز انتاجية الغاز الحيوي التي لها دور في تقليل التلوث البيئي من خلال الطارة المنارة المخلفات.

الكلمات المفتاحية: الغاز الحيوي؛ الهضم المشترك؛ الحرارية المائية؛ الموجات فوق الصوتية؛ قشور الرز؛ فضلات النعام 


\section{INTRODUCTION}

The global energy markets depend majorly on fossil fuel like coal, petroleum, diesel, and natural gas. Since fossil fuel formation requires trillions of years, its stock is finite and subjects to diminution (Saboor et al., 2017). However, ease of access to fossil fuels during almost two centuries has decreased the available fossil fuel reservoirs, causing rising prices. (Sari \& Budiyono, 2014). On the other hand, fossil fuel is considered as one of the main sources of global warming which emits carbon dioxide $\left(\mathrm{CO}_{2}\right)$, methane $\left(\mathrm{CH}_{4}\right)$, and some other trace gases, which result in many environmental problems and bad effects on human health and ecosystem. Therefore, the issue that has become a worldwide concern is the need for renewable, cheap, and clean energy sources, which has grown up with industrialization and global development of technology, as described by Noori (2017).

Anaerobic digestion (AD) has been defined as the biochemical process in which microorganisms breakdown the bulky organic molecule into smaller molecules under anaerobic conditions (Srivastava, 2020). Lignocellulosic biomass is the earth's most abundant and renewable resource, and, lignin is its strongest component such as hardwood, softwood, grasses, as well as household, industrial, and agriculture residues that can be used for sustainable methane production (Otieno and Ogutu, 2020; Zieliński et al., 2017).

Rice husks are agricultural wastes that remain after the processing of the rice crop, like rice straw and rice husk. Therefore, rice husks can be improved methane yield, as reported by Vivekanandan \& Kamaraj (2011). Lignocellulosic biomass material majorly includes cellulose, hemicellulose, and lignin, the arrangements of the contents inside the biomass makes it an extremely complex structure, as reported by Rehman et al. (2013). In order to improve biogas production from lignocellulosic biomass, a pretreatment process is necessary to disrupt naturally recalcitrant carbohydrateelignin shields that impair the accessibility of enzymes and microbes to cellulose and hemicellulose (Zheng et al., 2014). Besides, this led to the enhancement of lignin and hemicellulose removal, which allows hydrolytic reagents, improved access to the cellulose molecules in the subsequent hydrolysis steps (Rehman et al., 2013). From the pretreatments, Ultrasound, hydrothermal, combined hydrothermal-ultrasonic, alkaline, and combined alkaline-ultrasound pretreatment. A high alternating voltage is produced by ultrasound energy during the pretreatment of ultrasound. Ultrasound waves produce internal negative pressure, which in turn causes forming of small bubbles during the process of cell disruption. Ultrasound energy causes a stunning temperature and pressure, which lead to the destruction of the cell membrane (Liqian, 2011). Hydrothermal pretreatment of lignocellulosic biomass for enhanced bio-ethanol and biogas production is gaining the 21st century. Water under high pressure and temperature can penetrate into biomass, hydrate cellulose, and removes hemicellulose and part of lignin, the major advantages are no addition of chemicals and no requirements of corrosion-resistant materials for hydrolysis reactors in the hydrothermal pretreatment process (Chandra et al., 2012). Alkaline pretreatment, usually employing $\mathrm{NaOH}$, is known to break bond linkages between lignin in the lignocelluloses material, causing cellulose swelling which results in greater accessibility of the cellulose fraction (Talha et al., 2018). Combined pretreatments including hydrothermal-ultrasonic and $3 \% \mathrm{NaOH}-$ ultrasound pretreatment are applied, some studies have found that the synergies of matched and mixed pretreatments might optimize the overall outcome, as reported by Liqian (2011).

This study was aimed to investigate the influence of single pretreatment) ultrasonic, hydrothermal, $\mathrm{NaOH}$ $(3 \% \mathrm{w} / \mathrm{v}))$ and combined pretreatment (hydrothermalultrasonic, $3 \% \mathrm{NaOH}$, -ultrasonic) for rice husks on biogas production and on the characteristics of rice husks.

\section{MATERIALS AND METHODS 2.1 Preparing of Substrate and Inoculum 2.1.1 Preparing of Substrate}

$\mathrm{RH}$ was collected from a rice field in Al-Musayib city (Hilla, Iraq). After collection, the sample was manually cleaned to remove sand and undesirable particulates. The rice husk was air-dried for three days at $37-40{ }^{\circ} \mathrm{C}$. Then, they were milled by using an electrical household grinder and screened by using a mechanical screener to get a size of (0.3-0.6 mm). The size of the sample was selected depending on the previous work (Ismail and Noori, 2018). The Chemical characteristics of RH are shown in Table 1.

Table 1. Chemical characterizes of rice husks (RH) and ostrich dung (OD).

\begin{tabular}{ccc}
\hline Variables & RH & OD \\
\hline TS (\%) & 94.2 & 94.4 \\
VS (\%) & 82.08 & 32.52 \\
VS/TS & 0.88 & 0.34 \\
Cellulose content (\%) & 33 & - \\
Hemicellulose content (\%) & 25 & - \\
Lignin content (\%) & 20 & - \\
Carbon content (\%) & 48.58 & 18.86 \\
Nitrogen content (\%) & 0.52 & 2.33 \\
C/N & 93.42 & 8.09 \\
\hline
\end{tabular}




\subsubsection{Preparing of Inoculum}

Ostrich dung (OD) was used as bacterium sources in this study. Six fresh samples (one and two days old) were collected in the year 2019 from the ostrich farm in Al-Mahawil city, Babylon, Iraq. Then, it was airdried, crushed, and stored in a plastic container. The characteristic of OD is clarified in Table 1 . The inoculum was incubated at $35-37^{\circ} \mathrm{C}$ for 1 week to degrade easily degradable materials presented in them and to reduce non-specific biogas generation (Saboor et al., 2017; BundÓ et al., 2017). The slurry of inoculum was provided by blending $300 \mathrm{ml}$ of distilled water with $35 \mathrm{~g}$ of crushed OD. The mixed slurry was manually homogenized by glass rod, according to the procedure adopted by Ismail and Noori (2018).

\subsection{Pretreatment conditions}

To improve the capability of lignocellulosic RH to digestate through the anaerobic co-digestion, six pretreatments were applied which were ultrasound, hydrothermal, combined hydrothermal and ultrasound, alkaline with $\mathrm{NaOH}$ (98\%, provided by CA, USA), and combined alkaline with ultrasound pretreatment. The details of the pretreatments are explained in Table 2. Each pretreatment was performed using $30 \mathrm{~g}$ from ground $\mathrm{RH}$. Ultrasound pretreatment was performed by ultrasound cell crusher (Model: SJIA-1200W MTI, Germany). The temperature $\left(25^{\circ} \mathrm{C}\right)$ was selected depending on study Kavitha et al. (2016) who reported that the sonication was carried out at room temperature without any temperature regulation. While the time (15 min) was selected depending on study Sul'man et al. (2011) who reported that the optimum conditions for pretreatment of the substrate at which the most complete destruction of the plant material is achieved are an intensity of $368 \mathrm{~W} / \mathrm{cm}^{2}$ and a duration of no more than $15 \mathrm{~min}$., the frequency $(20 \mathrm{KHz}$, was selected depending on Kavitha et al., 2016), whereas the input power (480) was modified. In electrical autoclave (Model: DAIHAN LABTECH, Korea), the hydrothermal pretreatment was done. Pretreatment time (15 min) was selected according to (Alzate et al., 2012). The temperature $\left(121^{\circ} \mathrm{C}\right)$ and pressure (15 psi) were modified. The heating temperature $\left(80^{\circ} \mathrm{C}\right)$ used in alkaline pretreatment was carried out according to the previous research work (Hassan et al., 2016a) while the concentration of $\mathrm{NaOH}$ (3\%) and pretreatment time (3hr.) were modified.

\subsection{Biochemical Methane Potential (BMP) Set up}

BMP tests were used to compare the anaerobic biodegradability of pretreated and non-pretreated microalgal biomass (Fabiana and Ivet, 2015), six digesters were performed in a batch system. The digesters included rice husk in case of untreated ( $\mathrm{RH}-$ 1) and in case of pretreatments: $\mathrm{RH}-2, \mathrm{RH}-3, \mathrm{RH}-4$, RH-5, and RH-6. Figure (1) states, the arrangement of the lab-scale system used in this study for the anaerobic co-digestion process, which was depending on the previous study (Ismail \& Noori., 2018) with some modifications to dimensions. Each digester is represented by 500-mL Pyrex borosilicate. Inside each digester, the ratio of 1:10 was used according to previous research (Ismail \& Noori., 2018). This ratio indicated $30 \mathrm{~g}$ of solid waste: $300 \mathrm{ml}$ of inoculum slurry. A rubber stopper was used to plug each digester. Two ports in each one with $5 \mathrm{~mm}$ diameter. Glass tubes were submerged inside the digester through the two ports. A rubber tube was connected to each glass tube from the other end, which in turn connected to valves to curb the release of generated gas, according to previous research (Ismail \& Noori., 2018).

Before the start of each batch, the $\mathrm{pH}$ of all the reactors was determined after mixing the inoculum and substrate and was adjusted to $\mathrm{pH}=7$ if necessary by adding concentrated $\mathrm{HCl}$ solution after adding the inoculums and substrates, according to the procedure adopted by previous studies (Sambusiti et al., 2013; Saboor et al., 2017). In order to avoid aerobic respiration, oxygen in the headspace was replaced by the purging of nitrogen gas for 3-5mins. The introduced nitrogen will maintain an anaerobic environment and it will be helpful for a survey of methanogenic bacteria for effective biogas production. Then the digesters were closed tightly, as explained by Kannah et al. (2017).

Table 2. Pretreatment conditions in this study.

\begin{tabular}{|c|c|c|c|c|c|c|c|}
\hline $\begin{array}{c}\text { Pretreatment } \\
\text { type }\end{array}$ & Symbol & $\begin{array}{c}\% \\
\mathrm{NaOH}\end{array}$ & $\begin{array}{l}\text { Temperature } \\
\quad\left({ }^{\circ} \mathrm{C}\right)\end{array}$ & Time & $\begin{array}{l}\text { Frequency } \\
\text { kHz }\end{array}$ & $\begin{array}{l}\text { Input power } \\
\text { W }\end{array}$ & $\begin{array}{l}\text { Pressure } \\
\text { psi }\end{array}$ \\
\hline Untreated & RH-1 & - & - & - & - & - & - \\
\hline Ultrasound & RH-2 & - & $25^{*}$ & $15^{* *} \min$ & 20 & & - \\
\hline Hydrothermal & RH-3 & - & 121 & $15^{* * *} \min$ & - & - & 15 \\
\hline $\begin{array}{l}\text { Hydrotherm } \\
\text { al-ultrasonic }\end{array}$ & RH-4 & \multicolumn{6}{|c|}{ The same conditions of hydrothermal and ultrasonic were applied in this pretreatment } \\
\hline Alkaline & RH-5 & 3 & $80^{* * * *}$ & $3 \mathrm{~h}$ & - & 480 & - \\
\hline $\begin{array}{l}\text { Alkaline- } \\
\text { ultrasound }\end{array}$ & RH-6 & \multicolumn{6}{|c|}{ all above conditions were applied in this combined pretreatment } \\
\hline
\end{tabular}




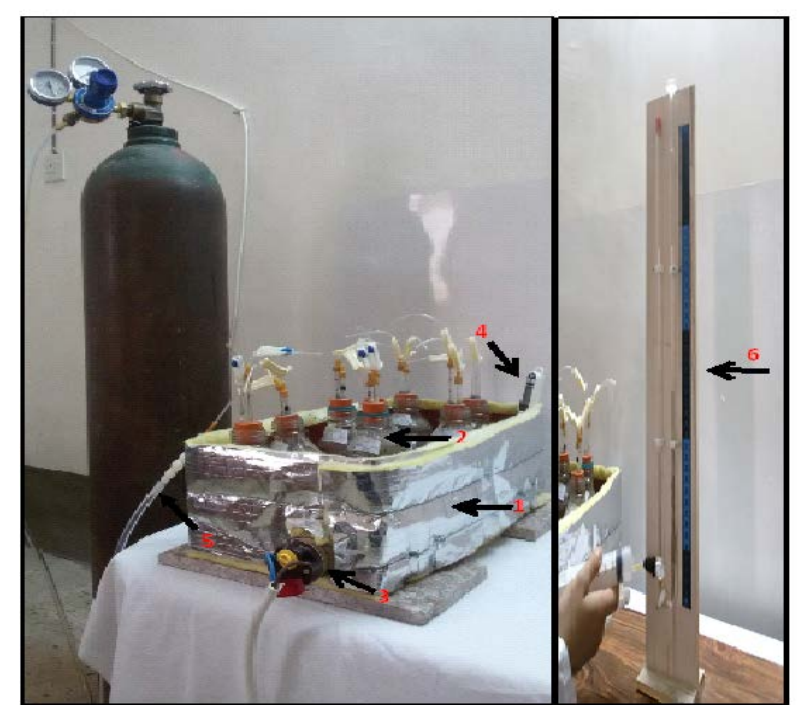

Figure 1. Experimental setup for a Biogas production system that composed of the main parts: (1): Water bath, (2) Activated digester, (3) Thermostat, (4) Digital thermometer, (5) Rubber tube for flushing nitrogen, and (6) Manometer.

Digesters were put in a thermostatic water bath (this arrangement was depending on the previous study (Noori, 2017) with some modifications) so that they remain in the required range of temperature which was $50{ }^{\circ} \mathrm{C}$ which was selected according to previous research, as described by Deepanraj et al. (2014).

\subsection{Analytical Methods}

Parameters like volatile solids (VS), total solids (TS), total nitrogen (TN), total carbon (TC) and lignocellulosic characteristics were analyzed for untreated and pretreated samples of RH. Also, TS, VS, TC and TN (TN was carried out using a Kjeldahl digestion system (England)) were estimated depending on the methods described by Ismail \& Noori (2018). The characterizes of lignocellulosic RH which include lignin, hemicellulose, and cellulose were determined depending on Van Soests method prescribed by Van Soest et al. (1991) using Raw fibres extractor (England). Finally, the produced biogas was measured daily by a manometer method, as described by Ismail \& Noori (2018).

\subsection{Kinetic Study}

For an anaerobic digester operating in a batch mode, the rate of biogas generation corresponds to a specific growth rate of methanogenic bacteria in this digester. Accordingly, the predicted rate of biogas production can be calculated using the Modified Gompertz Model (Ismail and Noori, 2018), the modified Gompertz model was carried out using (IBM SPSS 24.0.1FP2) analytical software. This non-linear regression model has been identified as a good empirical regression model commonly applied in the simulation of methane accumulation, because of its good enough precise prediction for different substrates (Talha et al., 2018):
$\mathrm{G}(\mathrm{t})=\mathrm{G}_{0} \cdot \exp \left\{-\exp \left[\frac{\text { Rmax.e }}{\mathrm{G}_{0}}(\lambda-\mathrm{t})+1\right]\right\}$

Where, $\mathrm{R}_{\max }$ is a maximum production rate of methane, $\mathrm{ml} / \mathrm{gVS} ; \mathrm{G}_{0}$ is the potential methane production, $\mathrm{ml} / \mathrm{gVS}$; $\mathrm{G}(\mathrm{t})$ is the accumulated biomethane at the time $\mathrm{t}, \mathrm{ml} / \mathrm{g}$. VS; $\mathrm{t}$ is measured time, day; $\lambda$ is the lag-phase, day; and e is $\exp (1)=2.7183$ (Talha et al., 2018; Ismail and Noori, 2018).

\section{RESULTS AND DISCUSSION}

\subsection{The Impact of Types Pretreatments on the Properties of Rice Husk}

The goal of the pretreatment process is to break down the lignin structure and disrupt the crystalline structure of cellulose so that acids or enzymes can easily access and hydrolyze cellulose, as reported by Kumar et al. (2009). In order to determine the influence of pretreatment with ultrasound ( $\mathrm{RH}-2)$, hydrothermal (RH-3), combined hydrothermalultrasonic (RH-4), $\mathrm{NaOH}(3 \% \mathrm{w} / \mathrm{v})(\mathrm{RH}-5)$, and combined $3 \% \mathrm{NaOH}$-ultrasound (RH-6) on the amount of cellulose, Hemicellulose and lignin content for RH were explained in Table 3.

Table 3 provides that all pretreatments the chemical composition of RH. The amount of cellulose content was increased from 33\% for RH-1 to become 35\% for RH-6. The highest cellulose content is again by RH-6 pretreatment. In RH-2 pretreatment, 15 and 20\% hemicellulose and lignin reduction were noticed, respectively, compared to an untreated sample (RH1 ), our results were in good acceptance with Sul'man et al. (2011) who suggested that ultrasound pretreatment caused lignin removal by $11.4 \%$ when it's used to treat lignocellulosic biomass. C/N (RH-2) was increased by $3.26 \%$ and reduction in TS and VS was obtained by 1.3 and 4\%, respectively, compared to an untreated sample (RH-1). For RH-3 pretreatment, all parameters including hemicellulose, lignin, TS, VS, and C/N were decreased by 13.04, 17, 1.55, 3.29 and 3.2\%, respectively, as compared with the untreated RH-1. The amount of TS, VS, C/N, hemicellulose and lignin was 90\%, 79.67\%, 63.19, $20.5 \%$ and $15.2 \%$ in the $\mathrm{RH}-4$ pretreatment, corresponding to a reduction of 4.46, 2.94, 32.36, 18, and $24 \%$, respectively, as compared to RH-1. In RH-5 pretreatment, the hemicellulose removal was $24 \%$ compared to $\mathrm{RH}-1$, while $31 \%$ was the removal of lignin, the $\mathrm{C} / \mathrm{N}$ ratio, TS was decreased by 25.13 and $2.23 \%$, respectively, while VS was increased by $3.34 \%$, as compared with $\mathrm{RH}-1$. Our results agree with the study Monlau et al., (2015) in which hemicellulose (26\%) with subsequent solubilization and removal of lignin (22\%), compared to untreated samples because of pretreatment of sunflower stalks with $4 \mathrm{~g} \mathrm{NaOH} / 100 \mathrm{~g}$ Total Solids (TS) at $55^{\circ} \mathrm{C}$ for 24 h. 
Table 3. Influence of the pretreatments on the characteristics of RH.

\begin{tabular}{ccccccc}
\hline Variable & $\begin{array}{c}\text { Cellulose } \\
\text { content } \\
(\%)\end{array}$ & $\begin{array}{c}\text { Hemicellulose } \\
\text { content } \\
(\%)\end{array}$ & $\begin{array}{c}\text { Lignin } \\
\text { content } \\
(\%)\end{array}$ & TS (\%) & VS (\%) & C/N \\
\hline RH-1 & 33 & 25 & 20 & 94.2 & 82.08 & 93.42 \\
RH-2 & 33.6 & 21.25 & 16 & 92.9 & 78.82 & 96.47 \\
RH-3 & 32.8 & 21.74 & 16.6 & 92.7 & 79.38 & 90.43 \\
RH-4 & 32.5 & 20.5 & 15.2 & 90 & 79.67 & 63.19 \\
RH-5 & 34.5 & 19 & 13.8 & 92.1 & 84.82 & 69.94 \\
RH-6 & 35 & 17.5 & 12.6 & 90.83 & 83.76 & 38.85 \\
\hline
\end{tabular}

The highest decrease was obtained during RH-6 pretreatment at 30, 37, 58.41and $3.58 \%$ for hemicellulose, lignin, $\mathrm{C} / \mathrm{N}$ ratio and TS, respectively, in comparison with RH-1. On the other hand, VS was slightly increased by $2.005 \%$. RH-6 pretreatment caused the difference in the chemical compositions and this difference earns it the preference compared to RH-2 and RH-5. Our results were agreed with previous research (Soontornchaiboon et al., 2016) which showed that the pretreatment by the combination of alkaline and ultrasound changed the chemical composition of all samples (corn cob, pineapple waste, bagasse, rice straw and water hyacinth), which was better than sole alkaline pretreatment.

\subsection{The Effect of Pretreatments for Rice Husk on the Generation of Biogas and Methane}

In this study, five pretreatments (RH-2, RH-3, RH-4, $\mathrm{RH}-5$ and $\mathrm{RH}-6$ ) were used to improve the production of biogas as compared to the control RH-1. Table 4 stated the cumulative productions of biogas and methane for all pretreated and untreated samples of $\mathrm{RH}$. The cumulative productions of biogas for $\mathrm{RH}-2$, RH-3, RH-4, RH-5 and RH-6 were 44.19, 39.5, 46.3, 47.16 and $52.38 \mathrm{ml} / \mathrm{g}$ VS, respectively; corresponding to biogas increment of 50.72, 34.72, 57.91, 60.85 and $78.65 \%$, respectively, as compared to its value of the control RH-1 which was equal to $29.32 \mathrm{ml} / \mathrm{g}$ VS for biogas production, as clarified in Figure (2). The cumulative productions of methane for $\mathrm{RH}-2$, $\mathrm{RH}-3$, RH-4, RH-5, and RH-6 were 30.73, 26.78, 32.24, 32.91 and $37.3 \mathrm{ml} / \mathrm{g}$ VS, respectively; corresponding to methane increment of $66.11,44.76,74.27,77.89$, and $101.62 \%$, respectively, as compared to its value the control RH-1 which was equal to $18.5 \mathrm{ml} / \mathrm{g}$ VS for methane yield, as clarified in Figure (3).

For RH-2 pretreatment, increasing in biogas and methane yield was due to the disruption of the structures of lignocellulosic biomass (hemicellulose and lignin), where lignin transforms most actively during the biodegradation of the pretreated substrate, due to the disruption of its bonds with cellulose upon ultrasonic treatment as reported by Sul'man et al.
Table 4. Effect of pretreatments on cumulative productions of biogas and methane.

\begin{tabular}{lll}
\hline Pretreatment & $\begin{array}{l}\text { Max. Biogas } \\
\text { production } \\
\text { (ml/g.VS) }\end{array}$ & $\begin{array}{l}\text { Max. Methane } \\
\text { yield } \\
\text { (ml/g.VS) }\end{array}$ \\
\hline RH-1 & 29.32 & 18.5 \\
RH-2 & 44.19 & 30.73 \\
RH-3 & 39.5 & 26.78 \\
RH-4 & 46.3 & 32.24 \\
RH-5 & 47.16 & 32.91 \\
RH-6 & 52.38 & 37.3 \\
\hline
\end{tabular}

(2011), and that was confirmed by the hemicellulose and lignin reduction in this study which was achieved in RH-2 pretreatment by 15 and 20\%, respectively, compared to the control RH-1, as explained in Table 3. Rehman et al. (2013) stated that ultrasound generates pressure with rapid cycling. In the rarefaction phase of this pretreatment, the pressure differentials within a solution cause growth and forming of cavitation microbubbles in the sonicated liquid. Thus, ultra-sonication produces both physical and chemical effects in the slurry being sonicated. All the above circumstances contribute to the pretreatment of lignocellulosic biomass. Our results agree with the previous study Deepanraj et al. (2014) reported that the ultrasonic pretreatment at $20 \mathrm{kHz}$ in the batch reactor on a palm oil mill and stated that the methane yield enhanced by $16 \%$. And, that increase in biogas production from $3657 \mathrm{~L} / \mathrm{m}^{3}$ of WAS (waste activated sludge) to $4413 \mathrm{~L} / \mathrm{m}^{3}$ of WAS an increase in methane production from $2507 \mathrm{~L} / \mathrm{m}^{3}$ of WAS to 3007 $\mathrm{L} / \mathrm{m}^{3}$ of WAS under optimal ultrasonic pretreatment conditions in a batch reactor.

For RH-3 pretreatment, the enhancements, which were stated above for biogas and methane yields, were because of the fact $\mathrm{s}$ it is efficient in penetration of the biomass, cellulose hydration, and removal of hemicellulose and part of lignin (Hesami et al., 2015). 
The major advantages are that there is no requirement for chemicals and corrosion-resistant material for the reactor. Typically, it can remove most of the hemicellulose and part of lignin in biomass by degrading them into soluble fractions and loosen the recalcitrant structure as well (Beltrán et al., 2019). The results obtained by $\mathrm{RH}-4$ pretreatment, which showed enhancement in both biogas and methane yields, were because the combined pretreatment was better than individual pretreatment. As RH-4 was combined of two pretreatments which were RH-2 and $\mathrm{RH}-3$, that enhanced its ability to increase biogas and methane production yields. Zheng et al. (2014) indicated that combined pretreatment could be beneficial due to higher methane yield and more biomass utilization compared to single pretreatment; however, it may also increase pretreatment costs. The results were in good agreement with the previous study reported by Trzcinski et al. (2015) who stated that combination ultrasonication and thermal pretreatment of sewage sludge resulted in a $20 \%$ increase in biogas production during the anaerobic digestion of the pre-treated sludge.

For RH-5 pretreatment, the results could be due to the fact that reported by Zheng et al. (2014) who stated that alkaline pretreatment is thought to be the cleavage and the saponification of carbohydrate-lignin linkages.

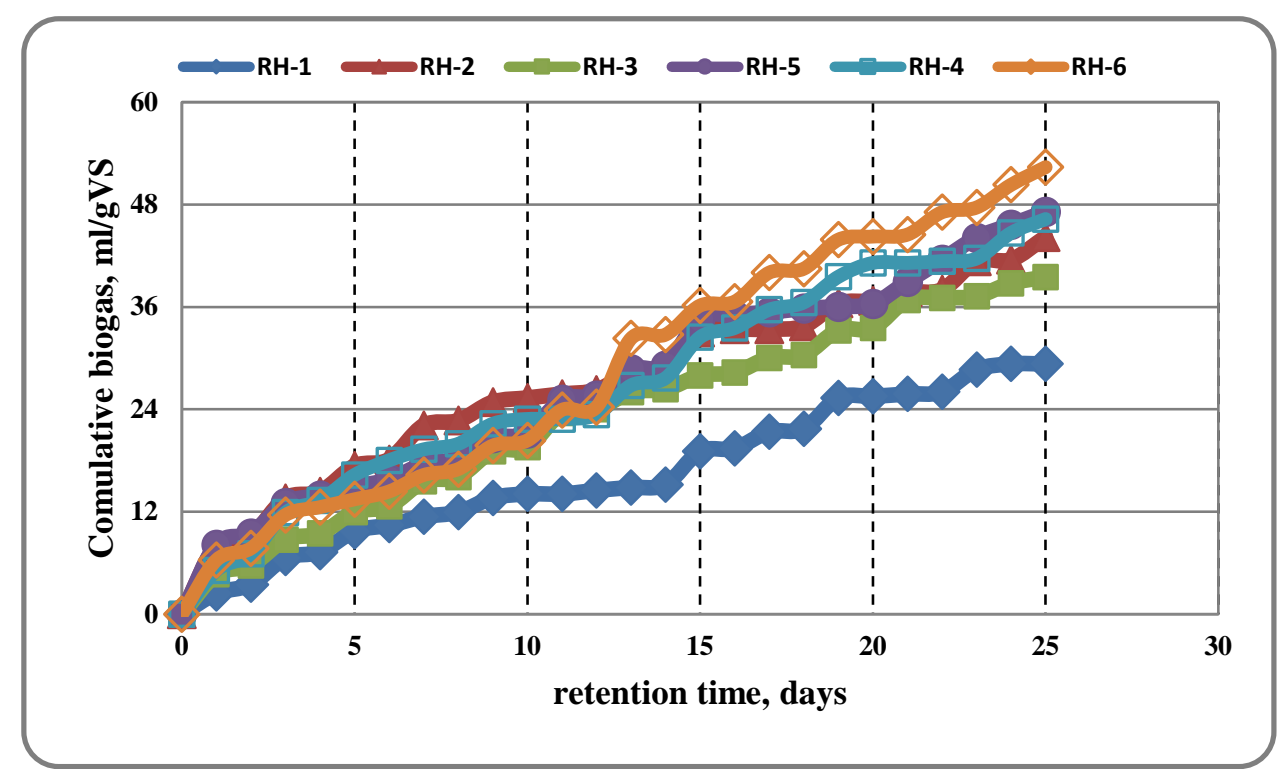

Figure 2. The cumulative production of biogas yield through the digestion process for all untreated and pretreated samples of RH.

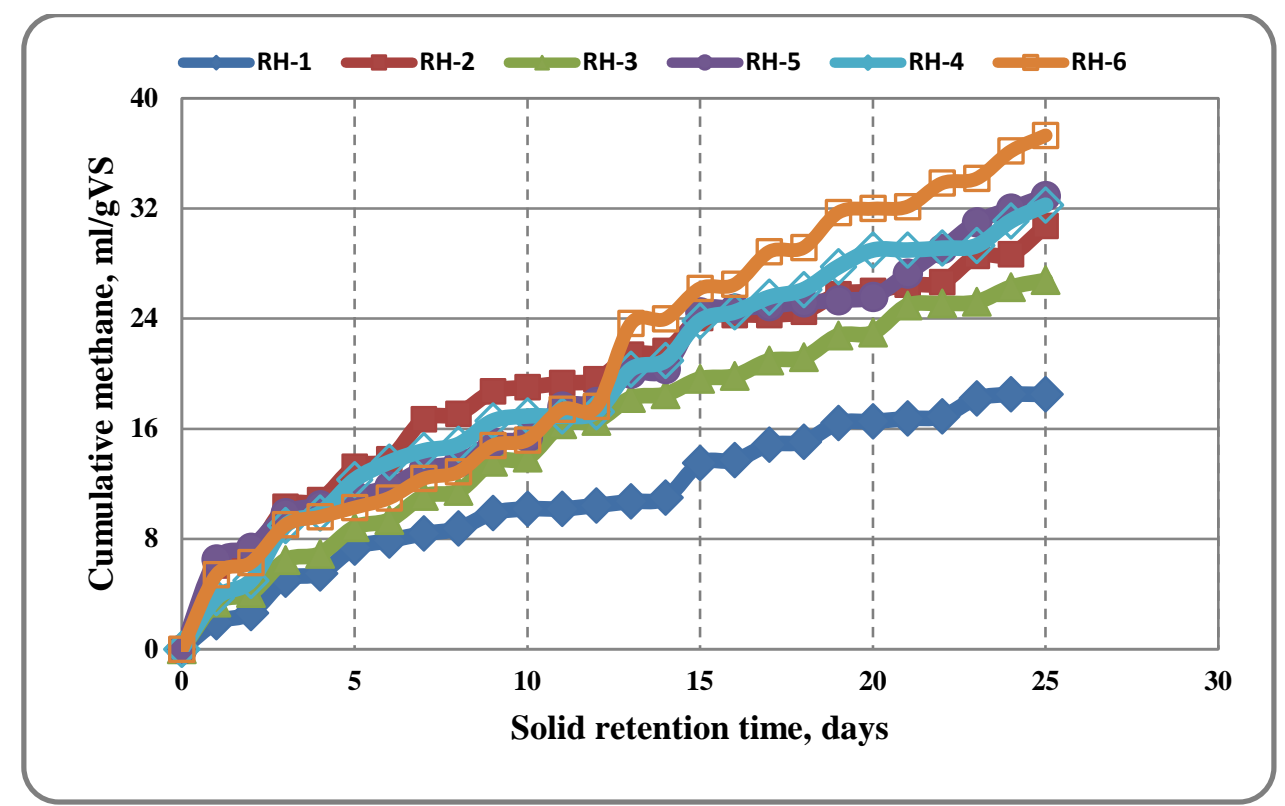

Figure 3. The cumulative production of methane yield through the digestion process for all untreated and pretreated samples of RH. 
By the removal of crosslinks, alkaline pretreatment leads to an increase of porosity, an internal surface area, structural swelling, a decrease in the degree of polymerization and crystallinity, disruption of lignin structure, and a breakdown of links between lignin and other polymers. The effective parameters should have increased the porosity of the substrate, which makes the carbohydrates more accessible for enzymes, as stated by Liqian (2011). Sambusiti et al. (2013) suggested that a 43\% increase in methane yield was noticed using pretreatment conditions 10\% $\mathrm{gNaOH} / \mathrm{g} \mathrm{TS}$ at $40{ }^{\circ} \mathrm{C}$ for wheat straw in batch mode in comparison with the control sample of wheat straw.

The results associated with $\mathrm{RH}-6$ pretreatment stated that it was better than $\mathrm{RH}-2$ and slightly higher than RH-5 in the production of biogas and methane yield. In addition, RH-6 was better in lignin reduction than RH-2 and RH-5, as stated in Table (3). This performance of $\mathrm{RH}-6$ pretreatment was due to that the combined pretreatment was better than single pretreatment. As RH-6 was combined with two pretreatments, which were $\mathrm{RH}-2$ and $\mathrm{RH}-5$, made the effect of RH-6 was stronger than the effect of $\mathrm{RH}-2$ or $\mathrm{RH}-5$ in the enhancement of biogas and methane yields. Our results had provided an obvious consistency with Talha et al. (2018) reported that the combined alkaline and ultrasonic treatment, with different $\mathrm{NaOH}$ loading rates $(0.25 \%-6 \%)$ and pre-treatment times, were applied to enhance methane yield (up to $39.49 \%$ ) compared to the untreated filter mud.

\subsection{Kinetic Study Using Modified Gompertz Model}

Figure (4a-f) and Table 5 present the results of the application modified Gompertz model, which explained that the estimated values and predicted values were incompatibilities with $\rho>0.95$.

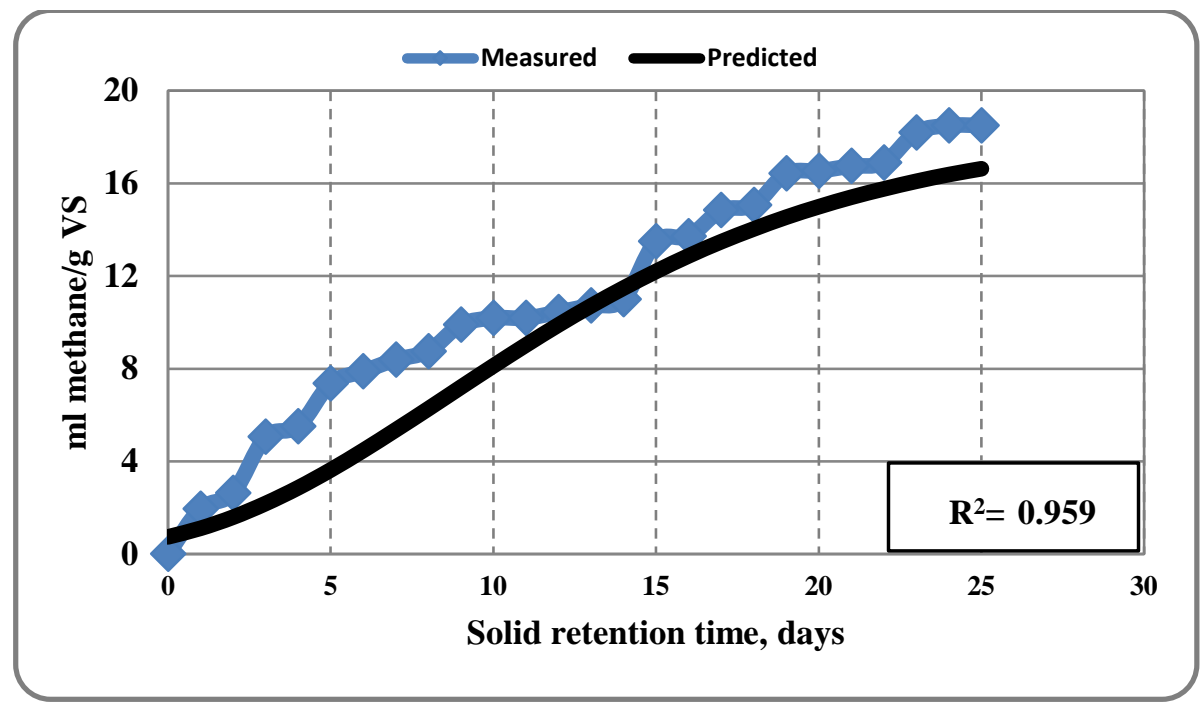

a: Predicted and measure results for $\mathrm{RH}-1$ pretreatment.

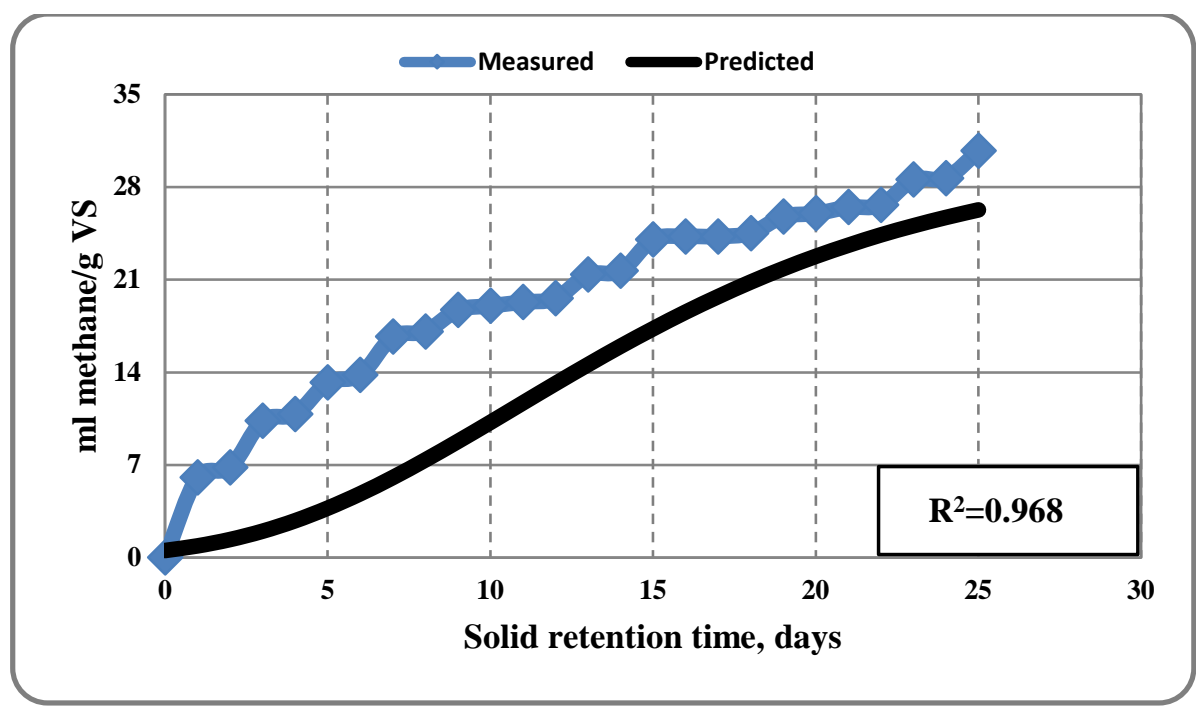

b: Predicted and measure results for $\mathrm{RH}-2$ pretreatment. 


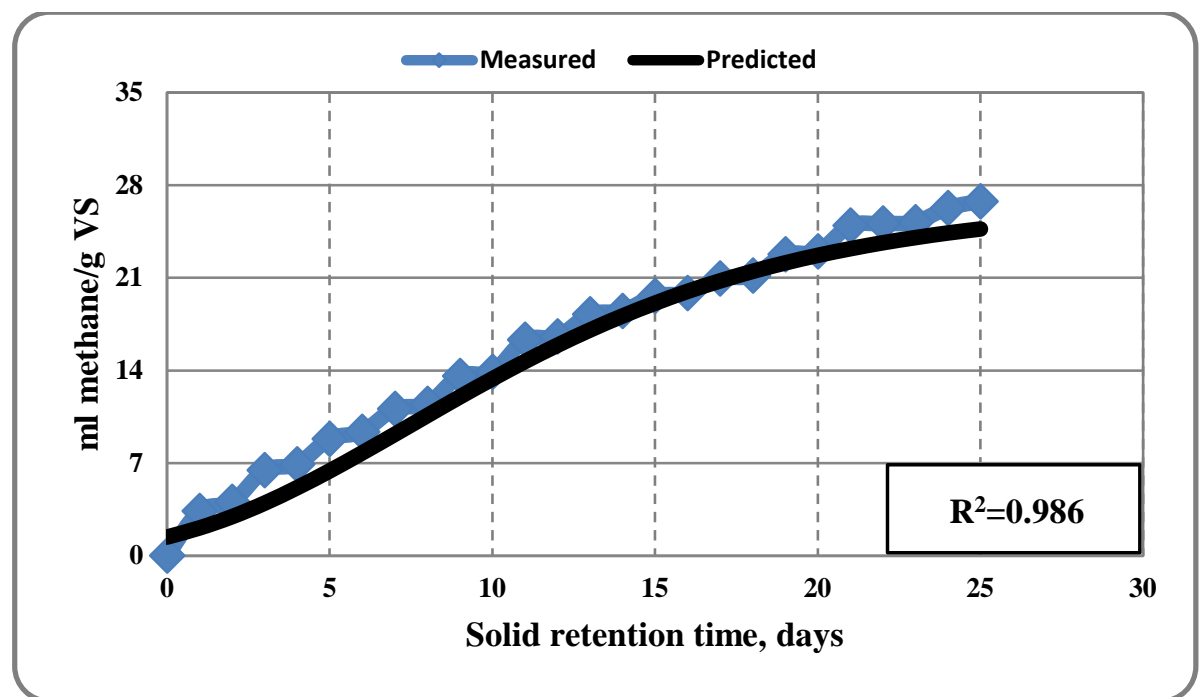

c: Predicted and measure results for RH-3 pretreatment.

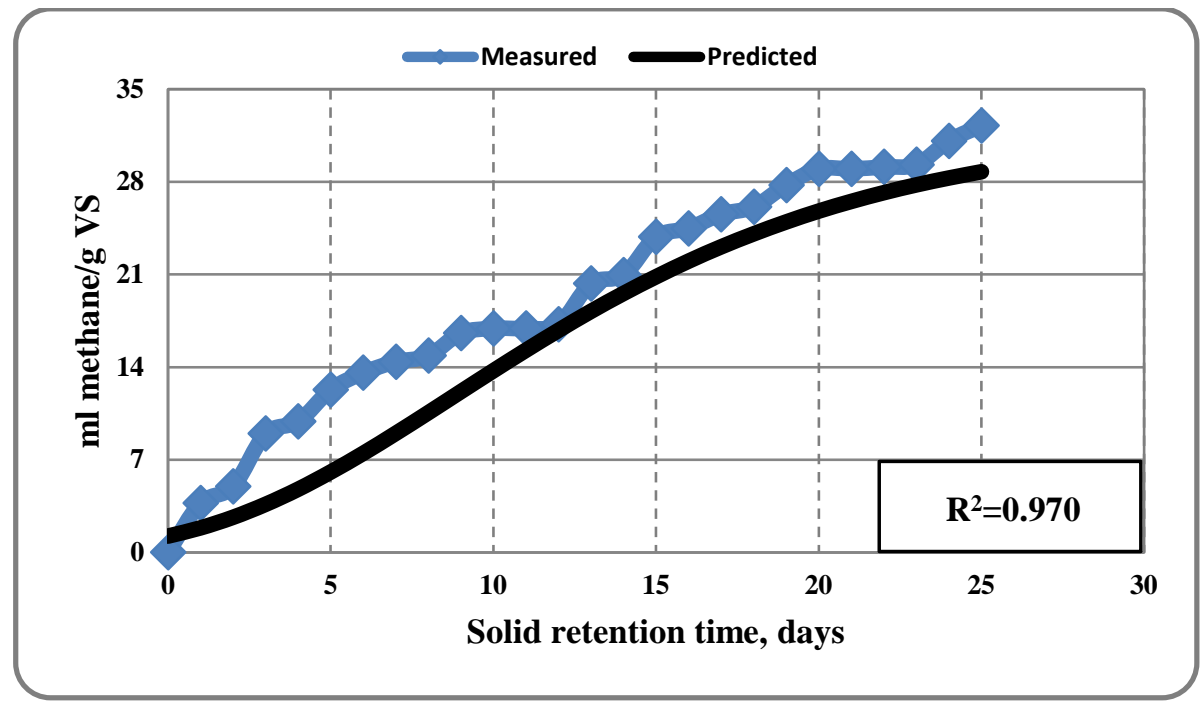

d: Predicted and measure results for RH-4 pretreatment.

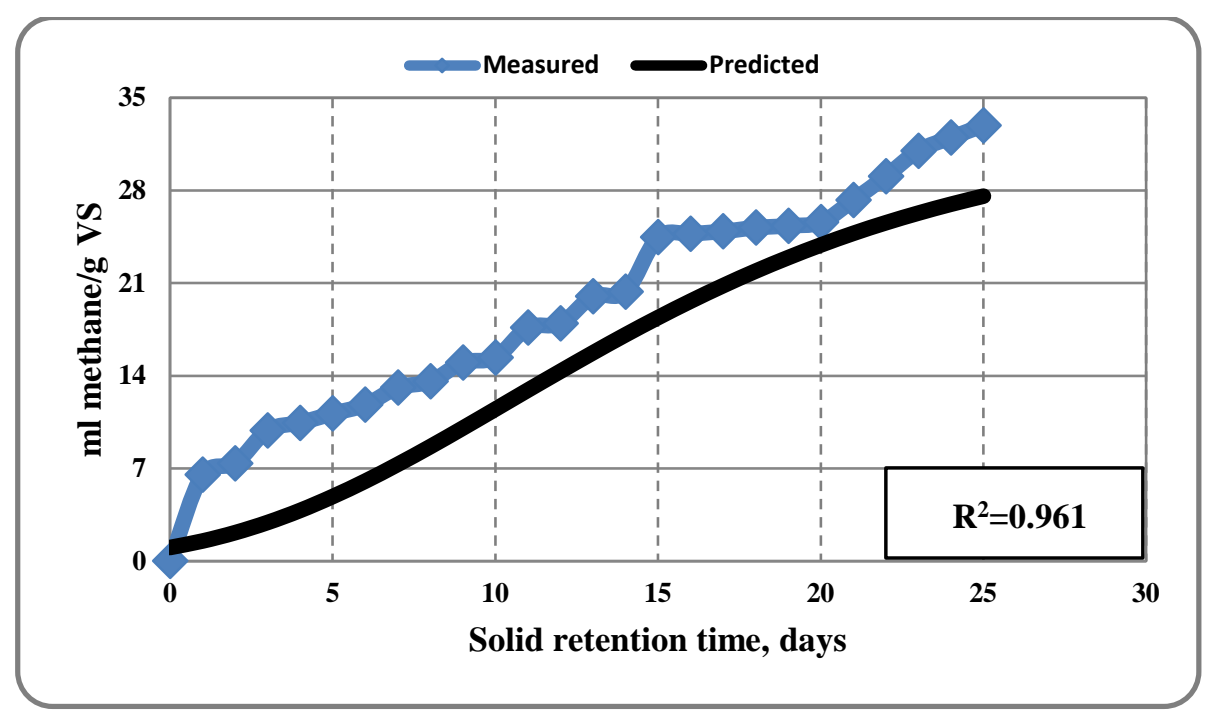

e: Predicted and measure results for RH-5 pretreatment. 


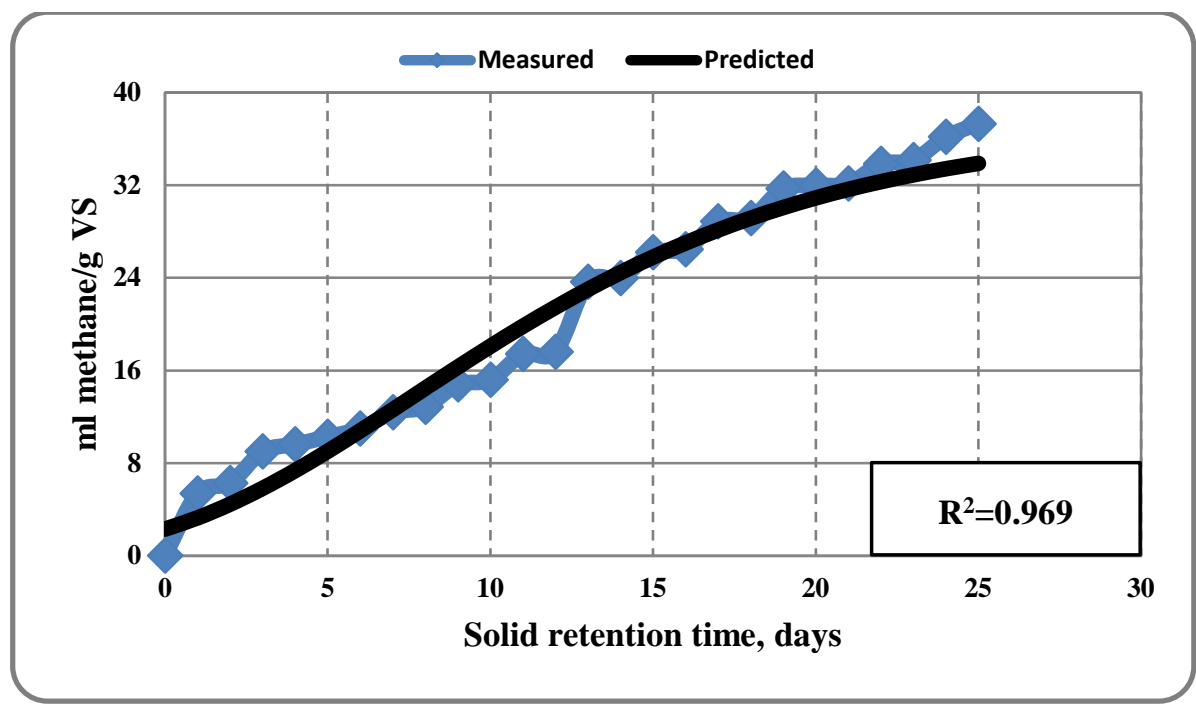

f: predicted and measure results for RH-6 pretreatment.

Figure 4. The predicted and measured results for methane yield to all the untreated and pretreated samples of RH for all rectors (a, RH-1); (b, RH-2); (c, RH-3); (d, RH-4); (e, RH-5); and (f, RH-6).

Table 5. Results from Performing Modified Gompertz Model.

\begin{tabular}{|c|c|c|c|c|c|c|}
\hline \multirow{2}{*}{$\begin{array}{l}\text { Digester } \\
\text { No. }\end{array}$} & \multirow{2}{*}{$\begin{array}{c}\mathrm{G}_{(\mathrm{t})} \exp . \\
(\mathrm{ml} \text { methane/g } \\
\text { VS) }\end{array}$} & \multicolumn{4}{|c|}{ Gompertz model parameters } & \multirow[t]{2}{*}{$\mathbf{R}^{2}$} \\
\hline & & $\begin{array}{c}\lambda \\
\text { (day) }\end{array}$ & $\begin{array}{c}R_{\max .} \\
\text { (ml methane/g } \\
\text { VS) }\end{array}$ & $\begin{array}{c}\mathrm{G}_{0} \\
\text { (ml methane/g } \\
\text { VS) }\end{array}$ & $\begin{array}{c}\mathrm{G}_{(\mathrm{t})} \text { model } \\
\text { (ml methane/g } \\
\text { VS) }\end{array}$ & \\
\hline 1 & 18.5 & 1.25 & 0.93 & 18.5 & 16.63 & 0.96 \\
\hline 2 & 30.73 & 3.04 & 1.47 & 30.73 & 26.27 & 0.97 \\
\hline 3 & 26.78 & 0.53 & 1.42 & 26.78 & 24.69 & 0.99 \\
\hline 4 & 32.24 & 1.36 & 1.59 & 32.24 & 28.76 & 0.97 \\
\hline 5 & 32.91 & 2.03 & 1.44 & 32.91 & 27.57 & 0.96 \\
\hline 6 & 37.3 & 0.17 & 1.8 & 37.3 & 33.88 & 0.97 \\
\hline
\end{tabular}

\section{CONCLUSION}

The results obtained from anaerobic co-digestion of pretreated rice husks inoculated with ostrich dung were most effective than those of untreated rice husks. In addition, the combined pretreatments for rice husks showed better results than solo pretreatment in biogas and methane production. The combined hydrothermal and ultrasonic pretreatment showed better productivity of biogas and methane than ultrasonic and hydrothermal pretreatments separately. Also, the combined alkaline and ultrasonic pretreatment showed better productivity of biogas and methane than alkaline and ultrasonic pretreatments separately. Best performance in biogas and methane increase for solo pretreatments was for alkaline pretreatment with $3 \% \mathrm{NaOH}$ by 60.85 and $77.89 \%$, respectively as compared with untreated rice husks. The combined alkaline and ultrasonic pretreatment were preferably recommended for biogas and methane enhancement, it caused an increase by 78.65 and $101.62 \%$, respectively, as compared to untreated rice husks.

\section{CONFLICT OF INTEREST}

The authors declare no conflict of interest.

\section{FUNDING}

No funding was received for this study.

\section{ACKNOWLEDGEMENT}

The authors would like to thank the Environmental Engineering Department and chemistry\& Microbiology Laboratory in the Biology Department/College of Science at the University of 
Babylon. Agriculture Department/ College of Agriculture at the University of Baghdad.

\section{REFERENCES}

Alzate M E, Muñoz R, Rogalla F, Fdz-Polanco F and Pérez-Elvira S I (2012), Biochemical Methane Potential of Microalgae: Influence of Substrate to Inoculum Ratio, Biomass Concentration and Pretreatment. Bioresource Technology 123: 488494.

Beltrán J U H, De Lira I O H, Santos M M C, Luevanos A S, Terán F H and Balagurusamy N (2019), Insight into Pretreatment Methods of Lignocellulosic Biomass to Increase Biogas Yield: Current State, Challenges, and Opportunities. Applied Science 9.

Bundó M S, Eskicioglu M G, Carrère H, Ferrer I (2017), Anaerobic Co-Digestion of Microalgal biomass and wheat straw with and without thermo alkaline pretreatment.

Chandra R, Takeuchi H, Hasegawa T, and Kumar R, (2012), Hydrothermal Pretreatment of Rice Straw Biomass: A Potential and Promising Method for Enhanced Biogas Production. Applied Energy 94: 129-140.

Deepanraj B, Velmurugan S and Jayaraj, S (2014), "Enhancement of Biogas Production by Pretreatmen," IV ${ }^{\text {th }}$ International Conference on Advance in Energy Research, Indian Institute of Technology Bombay, Mumbai, pp. 309-319.

Fabiana P, and Ivet F (2015), Influence of hydrothermal pretreatment on microalgal biomass anaerobic digestion and bioenergy production. water research 6 8: 364 -3 73 .

Hassan M, Ding W, Bi J, Mehryar E, Talha Z A A and Huang H (2016a), Methane Enhancement through Oxidative Cleavage and Alkali Solubilization Pre-treatments for Corn Stover with Anaerobic Activated Sludge. Bioresource Technology 200: 405-412.

Ismail Z Z, and Noori N A (2018), Anaerobic Codigestion of Giant Reed for Biogas Recovery. Journal of Engineering 24(3): 68-83.

Kannah R U, Kavitha S and Banu J R (2017), BMP A Tool for Assessing Energy Efficient Biogas Production. Biotechnology and Microbiology 5(2): 1-5.

Kavitha S, Brindha G M J, Gloriana A S, Rajashankar K, Yeom I T, and Banu J R (2016), Enhancement of Anaerobic Biodegradability Potential Municipal Waste Activated Sludge by Ultrasonic Aided Bacterial Disintegration. Bioresource Technology 200:161-169.

Kumar P, Barrett D M, Delwiche M J, Strove P (2009), Methods for Pretreatment of Lignocellulosic Biomass for Efficient Hydrolysis and Biofuel Production. Industrial Engineering and Chemistry Research 48: 3713-3729.

Liqian W (2011), Different Pretreatments to Enhance Biogas Production: A Comparison of Thermal,
Chemical and Ultrasonic Methods, M. S. Thesis, University of Halmstad, Sweden.

Monlau F, Kaparaju P, Trably E, Steyer J P and Carrere H (2015), Alkaline Pretreatment to Enhance One-Stage CH4 and Two-Stage $\mathrm{H}_{2} / \mathrm{CH}_{4}$ production from Sunflower Stalks: Mass, Energy and Economical Balances. Chemical Engineering Journal 260: 377-385.

Noori N A (2017), Sustainable Approach Biogas Recovery from Co-digestion of Giant Reed for Clean Energy Production, M. S. Thesis, University of Baghdad, Iraq.

Otieno J O and Oguto F O (2020), A Review of Potential of Lignocellulosic Biomass for Bioethanol Production in Kenya. Asian Journal of Chemical Sciences 8(2):34-54.

Rehman M S U, Kim I, Chisti Y and Han J I (2013), Used of Ultrasound in the Production of Bioethanol from Lignocellulose Biomass. Energy Education Science and Technology Part A: Energy Science and Research 30(2):1931-1410.

Saboor A, Khan S, Shah A A, Hasan F, Khan Haji and Badshah M (2017), Enhancement of Biomethane Production from Cattle Manure with Codigestion of Dilute Acid Pretreated Lignocellulose. International Journal of Green Energy 14: 632-637.

Sambusiti C, Monlau F, Ficara E, Carrère H and Malpei F (2013), A Comparison of Different Pretreatments to Increase Methane Production from Two Agricultural Substrates. Applied Energy 104: 62-70.

Sari F P and Budiyono (2014), Enhanced Biogas Production from Rice Straw with Various Pretreatment: A review. Waste Technology 2(1):17-25.

Soontornchaiboon W, Kim S M, Pawongrat R (2016), Effects of Alkaline Combined with Ultrasonic Pretreatment and Enzymatic Hydrolysis of Agricultural Wastes for High Reducing Sugar Production. Sains Malaysiana 45(6): 955-962.

Srivastava S K (2020), Advancement in biogas production from the solid waste by optimizing the anaerobic digestion. Waste Disposal Sustainability Energy 2:85-103.

Sul'man E M, M G Sul'man, and Prutenskaya E A (2011), Effect of Ultrasonic Pretreatment on the Composition of Lignocellulosic Material in Biotechnological Processes. Biocatalysis 3(1): 2833.

Talha Z, Hamid A, Guo D, Hassan M, Mehryar E, Okinda1 C and Ding W (2018), Ultrasound Assisted Alkaline Pre-Treatment of Sugarcane Filter Mud for Performance Enhancement in Biogas Production. International Journal of Agricultural and Biological Engineering 11(1): 226-231.

Trzcinski A P, Tian X, Wang C, Lin L L and Ng W J (2015), Combined Ultrasonication and Thermal Pre-Treatment of Sewage Sludge for Increasing 
Methane Production. Journal of Environmental Science and Health, Part A 50: 213-223.

Van Soest P J, Robertson J B and Lewis B A (1991), Symposium: Carbohydrate Methodology, Metabolism, and Nutritional Implications in Dairy Cattle, Journal of Dairy Science, 74 (10).

Vivekanandan S and Kamaraj G (2011), The Study of Biogas Production from Rice Chaff (Karukka) as Co-Substrate with Cow Dung. Indian Journal of Science and Technology 4(6): 657- 659.
Zheng Y, Zhao J, Xu F and Li Y (2014), Pretreatment of lignocellulosic Biomass for Enhanced Biogas Production. Progress in Energy and Combustion Science 42: 35-53.

Zieliński M, Dęowski M, Kisielewaska M, Noweska A, Rokicka M, Szware K (2017), Comparision of Ultrasonic and Hydrothermal Cavitaions Pretreatments of Cattle Manure Mixed with Wheat Straw on Fermentative Biogas Production. Waste Biomass Ware. 